\title{
Polyploidy in tissues of plants in vitro of grape somaclones
}

\author{
Viktor Klimenko ", Ekaterina Lushchay, and Valeryi Zlenko \\ All-Russian National Research Institute of Viticulture and Winemaking «Magarach», 31 str. Kirova, \\ Yalta, Republic of Crimea, 298600, Russia
}

\begin{abstract}
In vitro experimental plants obtained by clonal micropropagation of 9 grape somaclones of 5 original forms were the material for cytogenetic research. A biological microscope XSP-146TP was used for cytogenetic analysis. 823 cases of deviation from diploidy were observed in total. Significant tissue ploidy was observed in the meristematic tissue of in vitro plants of grape somaclones obtained by colchicine treatment of proembryogenic cells of various varieties. The significant direct correlation was found between the frequency of polyploidy in meristem tissues of in vitro plants and the number of chloroplasts in the stomata of grape somaclones. The reverse correlation was found between the frequency of polyploidy and the number of stomata on the leaf area. Somaclone No. 72 , obtained as a result of regeneration from colchicinated proembryogenic cells of the Ruta grape variety and identified as a tetraploid $(2 n=4 x=76)$, is recommended for use in the polyploid creation program.
\end{abstract}

\section{Introduction}

Somatic embryogenesis is one of the best methods of plant micropropagation. It is effectively used to remove phytopathogens from infected plant materials [1]. At the same time, somatic embryogenesis has an increased risk of anomalies due to somaclonal variations [2], which is a disadvantage for large-scale propagation and a positive moment for obtaining polyploid forms. Achieving the undoubted advantages that polyploid organisms possess is the aim of many breeders who use induced polyploidy and natural polyploids to create new plant varieties [3]. Polyploid forms of plants are characterized by increased organ sizes compared to diploid varieties, buffering of harmful mutations, increased heterozygosity and heterosis [3-5]. Polyploidy allows obtaining seedless varieties due to errors that occur in meiosis; at the same time, doubling the genome in a sterile hybrid allows restoring its fertility $[3,6]$.

It is necessary to take into account when choosing the method of polyploidization that the effectiveness of the action of an antimitotic agent depends on its concentration, duration of exposure, genotype of the original form, germination and survival of seeds [7]. During the study of the possibility of polyploidy induction in grapes by treating the apical meristem with colchicine, it turned out that the tested genotypes practically did not respond to the effect of colchicine in the direction of genome doubling [8]. The results of the experiment with hybrid

* Corresponding author: vik klim@,rambler.ru 
progeny of Muscadinia rotundifolia, Vitis riparia and Vitis rupestris, obtained using various combinations of explants, antimitotic agents, their exposure time and concentration, allowed to create an effective protocol for the induction of in vitro tetraploids for rootstock breeding programs [9]. The application of the response surface methodology to determine the optimal conditions for obtaining plants in experiments on polyploidization of shoot tops and somatic embryoids of seedless grape varieties made it possible to obtain non-chimeric autotetraploid plants with a frequency higher than $30 \%$ [10]. According to reports, the effect of colchicine on proembryogenic cells of suspension cultures leads to the regeneration of true autopolyploids [11]., The basic schemes and individual features of subcultivation of proembryogenic callus, suspensions and somatic embryoids of 6 grape varieties were identified to determine the most effective protocols for polyploidy induction [12].

The purpose of this study is to evaluate the occurrence of polyploid cells in the meristematic tissue of in vitro plants, obtained by clonal micropropagation of a number of grape somaclones.

\section{Materials and methods}

Laboratory studies were conducted at the Magarach Institute, Yalta, in 2019-2021. In vitro plants obtained by clonal micropropagation of 9 grape somaclones of 5 original forms was the material for cytogenetic research. The original forms of somaclones are varieties and hybrids of the genus Vitis (Tournef.) Linn. Grape somaclones were obtained according to the protocols developed at the Magarach Institute (treatment of proembryogenic cells with colchicine, development of somatic embryoids from colchicinated cells of suspension cultures and regeneration of somaclone plants from them) [13]. Cytogenetic analysis was performed according to the methods recommended for grapes [14]. Roots 3-5 mm long of in vitro plants were used as objects, the meristem of root growth points was studied. 3-5 temporary acetocarmine preparations were made for each variant. The biological microscope XSP-146TP ("Ulab", TM) and the digital video camera INOVO Granum DC 1300 USB2.0CAM ("NVL Granum", Ltd.) were used for cytogenetic analysis. The proportion of polyploid cells was calculated as the ratio of the number of tetraploid cells to the total number of cells in the metaphase and expressed as a percentage.

Statistical data processing was carried out according to generally accepted methods using the application software package Statistica 10 (StatSoft, Inc., USA). The experiments were carried out in three replicates. The values of the mean $(M)$, standard deviations $( \pm S D)$ and Pearson pair correlation coefficients were calculated. They are presented in the tables. The reliability of the difference between the variants was evaluated using the Student's t-test. The differences between the variants were considered statistically significant at a significance level of $\mathrm{p} \leq 0.05$.

\section{Results and discussion}

All stages of mitosis were observed during cytogenetic experiments. 4745 cells were found in the state of division in total (Table 1).

Deviations from diploidy with the number of chromosomes $2 \mathrm{n}=2 \mathrm{x}=38$ were encountered and taken into account in the meristematic tissue of somaclones at the metaphase stage (Fig.). 823 cases of deviation from diploidy were observed in total. Somaclone No. 72 is actually a tetraploid form $(2 n=4 x=76)$, although a certain share of diploid cells is present in its tissues. Most likely, somaclone No. 89 (the original form of the Sphinx grape variety) and somaclone No. 76 (the original form of E-342) can also be selected and identified as tetraploid forms during dischimering. 
Table 1. Results of evaluation of polyploidy in grape somaclones regenerated from colchicinated proembryogenic cells

\begin{tabular}{|l|c|c|c|}
\hline Variety & $\begin{array}{c}\text { Original form, } \\
\text { somaclone }\end{array}$ & $\begin{array}{c}\text { Number of cells, } \\
\text { pcs. }\end{array}$ & $\begin{array}{c}\text { Frequency of tetraploid cells, } \\
\%\end{array}$ \\
\hline Bianca & original form & 305 & 0 \\
\hline Bianca & 40 & 316 & $2,6 \pm 0,7^{\mathrm{a}}$ \\
\hline Ruta & original form & 332 & 0 \\
\hline Ruta & 48 & 406 & $2,6 \pm 0,6^{\mathrm{a}}$ \\
\hline Ruta & 61 & 311 & $95,7 \pm 1,8^{\mathrm{b}}$ \\
\hline Ruta & 72 & 348 & $3,3 \pm 0,3^{\mathrm{a}}$ \\
\hline Ruta & 82 & 515 & $0,2 \pm 0,2^{\mathrm{a}}$ \\
\hline Ruta & 96 & 610 & 0 \\
\hline Sfinks & original form & 315 & $54,2 \pm 0,7^{\mathrm{c}}$ \\
\hline Sfinks & 89 & 322 & 0 \\
\hline E-342 & original form & 302 & $71,3 \pm 1,7^{\mathrm{d}}$ \\
\hline E-342 & 76 & 351 & $10,0 \pm 1,9^{\mathrm{e}}$ \\
\hline E-342 & 94 & 312 & \begin{tabular}{c}
$\mathrm{c}$ \\
\hline
\end{tabular}
\end{tabular}

$\mathrm{N}$ o t e. Values with different letters have statistically significant differences at $\mathrm{p} \leq 0.05$.
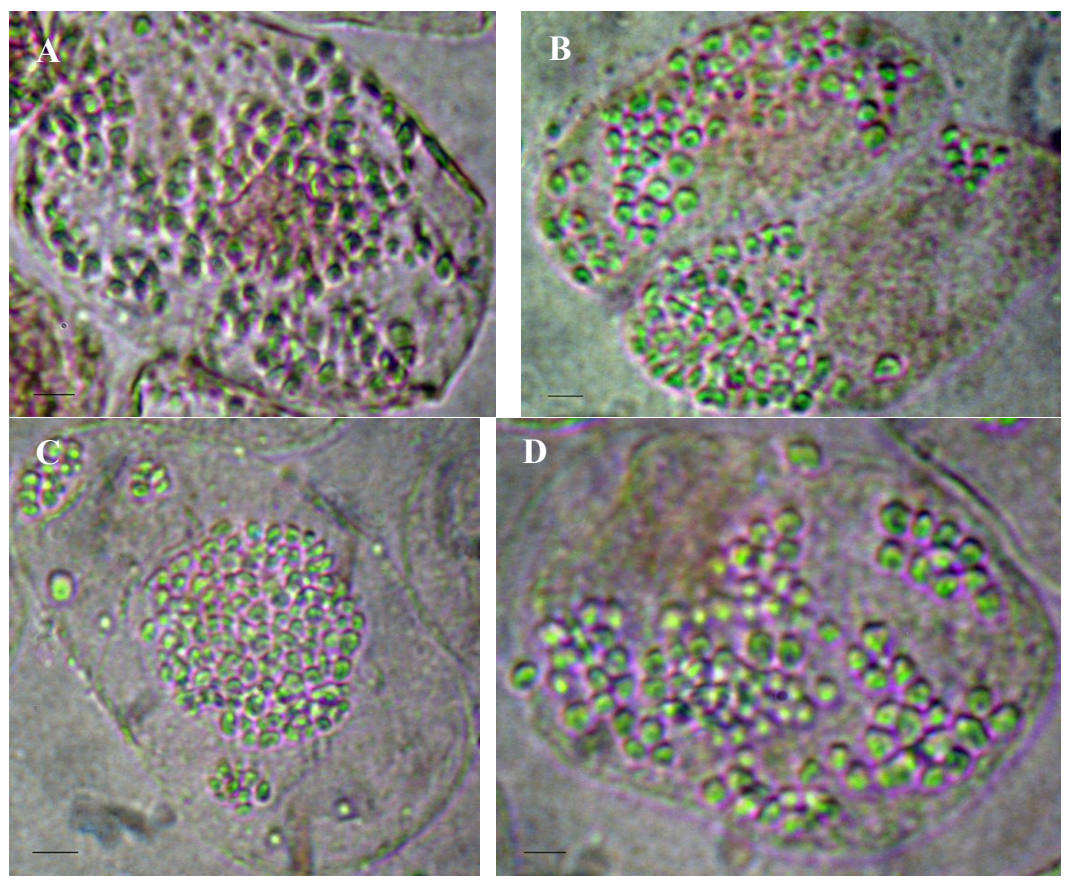

Fig. Polyploid cells in tissues of in vitro plants of grape somaclones regenerated from colchicinated proembryogenic cells: A - somaclone No. 72 (Ruta); B - somaclone No. 76 (E-342); C - somaclone No. 89 (Sphinx); D - somaclone No. 94 (E-342). The scale is 5 microns 
Mixoploid chimeras are one of the most common results of work in the field of induced polyploidy [15]. It is necessary to identify cytochymeras, plants whose ploidy level differs in different types of tissues, when using polyploids in plant breeding. The appearance of chimeras instead of stable tetraploid plants indicates that there was no simultaneous effect of antimitotic agents on all cells present in all three histogenic layers of meristem tissues [16]. The probability of chimericalness is expected to be minimal under the condition of treatment of proembryogenic cells. However, somatic segregation leads to the appearance of cells with an unequal number of chromosomes in the tissues. This phenomenon can be caused by various reasons, including endomitosis [14]. Mixoploidy was also observed in the cells of experimental in vitro grape plants obtained from stenospermocarpic seeds, as well as in the meristematic tissue of the mutant grape variety Aurora Magaracha [14, 17].

Recently, an indirect method for assessing plant ploidy has been widely used, based on the revealed relationships of genome ploidy with morphological features of the leaf epidermis $[8,9,10]$. In this work, the significant direct correlation was found between the frequency of polyploidy in meristem tissues of in vitro plants and the number of chloroplasts in the stomata of grape somaclones. The reverse correlation was found between the frequency of polyploidy and the number of stomata on the leaf area. (Table 2).

Table 2. Correlation coefficient between the frequency of tetraploid cells and the parameters of in vitro plants stomata of grape somaclones

\begin{tabular}{|l|c|c|}
\hline \multicolumn{1}{|c|}{ Sign of the abaxial epidermis } & $\begin{array}{c}\text { Correlation coefficient } \\
\text { with the frequency of tetraploid } \\
\text { cells }\end{array}$ & $\mathrm{p}$ \\
\hline $\begin{array}{l}\text { The number of chloroplasts per 1 stomata, } \\
\text { pcs. }\end{array}$ & 0,738 & 0,004 \\
\hline Stomata length, microns & 0,510 & 0,075 \\
\hline Stomata width, microns & 0,149 & 0,627 \\
\hline The number of stomata per $1 \mathrm{~mm}^{2}$, pcs. & $-0,648$ & 0,017 \\
\hline
\end{tabular}

Somaclones, which have a noticeable number of deviations from diploidity, show differences from the original forms in a number of signs of the leaf epidermis: somaclone No. 89 exceeds the Sphinx original form in the number of chloroplasts, in the length of the stomata and has a lower density of stomata; somaclone No. 76 also has a larger number of chloroplasts and a lower density of stomata than the E-342original form; somaclone No. 72 exceeds the Ruta original form in all parameters of ploidy indirect assessment.

The relationship between the level of plant ploidy and various signs was found in different species. However, some problems, such as dependence on the environment and the identification of mixoploids instead of polyploids, limit the use of these signs to determine the level of ploidy [16]. Although the biological significance of the relationship between the genome and stomata size in autopolyploids is controversial, a comparison between the size of epidermal structures and ploidy is useful for the study of grape polyploids induced in vitro [10]. The results obtained in this work are the basis for preliminary working hypotheses and suggest their verification in the course of further research in order to identify certain patterns of the occurrence of true tetraploids.

\section{Conclusion}

Thus, a significant ploidy of tissues is observed in the meristematic tissue of in vitro plants of grape somaclones obtained by colchicine treatment of proembryogenic cells of various varieties. Somaclone No. 72, obtained as a result of regeneration from colchicinated 
proembryogenic cells of the Ruta grape variety and identified as a tetraploid $(2 n=4 x=76)$, is recommended for use in the polyploid creation program. The results of the study can be used in applied genetics and vine practical selection when breeding new varieties.

\section{References}

1. A.I. Bhat, G.P. Rao, In: Characterization of Plant Viruses, 479-489 (Humana, New York, NY, 2020) https://doi.org/10.1007/978-1-0716-0334-5 48

2. D.A. Golino, M. Fuchs, S. Sim, K. Farrar, G. Martelli, In: Grapevine Viruses: Molecular Biology, Diagnostics and Management, 561-579 (Springer, Cham, 2017) https://doi.org/10.1007/978-3-319-57706-7 27

3. M.C. Sattler, C.R. Carvalho, W.R. Clarindo, Planta, 243, 281-296 (2016) https://doi.org/10.1007/s00425-015-2450-x

4. S. A. Julião, Cd. V. Ribeiro, J. M. L. Lopes, E. Md. Matos, A. C. Reis, P. H. P. Peixoto, M. A. Machado, A. L.S. Azevedo, R. M. Grazul, J. M. Sd. Campos, L. F. Viccini, Front. Plant Sci., 11, 292 (2020) https://doi.org/10.3389/fpls.2020.00292

5. Y. L. Longa, F. Qiaoc, X. F. Jianga, H. Q. Congc, M. L. Suna, Z. J. Xu, Braz. J. Biol., 79(2), 180-190 (2019) https://doi.org/10.1590/1519-6984.174475

6. D. H. Touchell, I. E. Palmer, T. G. Ranney, Front. Plant Sci., 11, 722 (2020). https://doi.org/10.3389/fpls.2020.00722

7. V. M. Kuliyev, Cytol. Histol. Int. J., 4(1), 1-6 (2020)

8. Z. Kara, A. Sabir, K. Yazar, O. Doğan, M. M. Şit, Selcuk J. Agric. Food. Sci., 32 (3), 424429 (2018) https://doi.org/10.15316/SJAFS.2018.117

9. X. Xie, C. B. Agüero, Y. Wang, M. A. Walker, Plant Cell Tiss. Organ. Cult., 122, 675-683 (2015) https://doi.org/10.1007/s11240-015-0801-8

10. I. Sinski, D. Dal Bosco, N. I. Pierozzi, J. D. G. Maia, P. S. Ritschel, V. Quecini, Euphytica, 196(2), 299-311 (2014) https://doi.org/10.1007/s10681-013-1034-8

11. Y. Acanda, O. Martinez, M. U. Ganzalez, M. J. Prado, M. Rey, Plant Cell Tiss. Organ. Cult., 123(3), 547-555 (2015) https://doi.org/10.1007/s11240-015-0859-3

12. V. A. Zlenko, V. V. Likhovskoy, V. A. Volynkin, P. A. Khvatkov, I. A. Vasylyk, S. V. Dolgov, Biotechnol., 33(5), 35-44 (2017) https://doi.org/10.21519/0234-2758-201733-5-35-44

13. V. A. Zlenko, V. P. Klimenko, I. A. Pavlova, E. A. Lushchay, A. V. Petyhova, A. S. Abdurashitova, V. V. Likhovskoi, Magarach. Viticulture and Winemaking, 22(3), 190-195 (2020) https://doi.org/10.35547/IM.2020.22.3.001

14. V. P. Klimenko, Russ. J. Dev. Biol., 50(2), https://doi.org/10.1134/S1062360419020024

15. X. Wang, Z.-M. Cheng, Sh. Zhi, F. Xu, Czech J. Genet. Plant Breed., 52(2), 41-54 (2016) https://doi.org/10.17221/151/2015-CJGPB

16. A. Manzoor, T. Ahmad, M. A. Bashir, I. A. Hafiz, C. Silvestri, Plants, 8(7), 194 (2019) https://doi.org/10.3390/plants8070194

17. V. P. Klimenko, Meždunar. naučno-issled. ž., $\quad$ 2(92), $\quad$ Part 1, $\quad 130-134 \quad$ (2020) https://doi.org/10.23670/IRJ.2020.92.2.025 